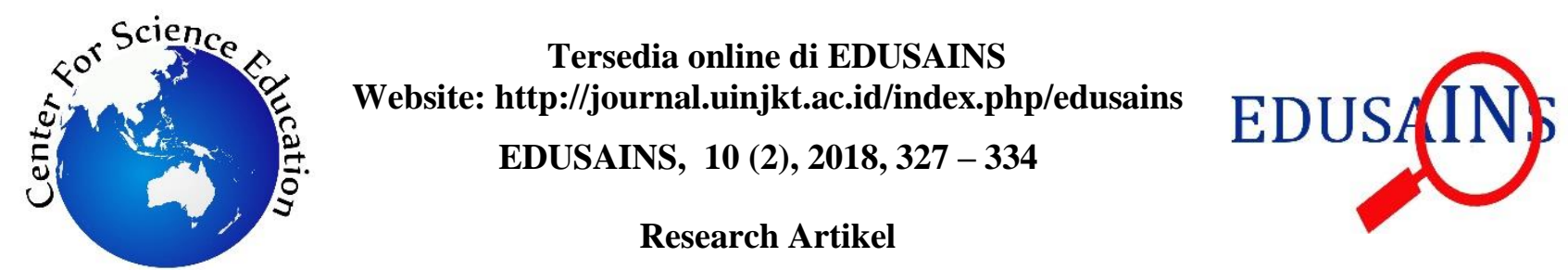

\title{
AN EFFECTIVE OF POGIL WITH VIRTUAL LABORATORY IN IMPROVING SCIENCE PROCESS SKILLS AND ATTITUDES: SIMPLE HARMONIC MOTION CONCEPT
}

\author{
EFEKTIVITAS POGIL DENGAN LABORATORIUM VIRTUAL DALAM PROSES \\ MENINGKATKAN KETERAMPILAN DAN SIKAP ILMU PENGETAHUAN: KONSEP MOTION \\ MOTION SIMPLE HARMONIC
}

Fathiah Alatas, Ziah Fachrunisa

Universitas Islam Negeri Syarif Hidayatullah, Indonesia

fathiah.alatas@uinjkt.ac.id

\begin{abstract}
Simple harmonic motion is a concept that often involve complex and difficult equations, so that students can't construct knowledge of the concept. This research applies POGIL with a virtual laboratory, where students are encouraged to construct the concept and emphasize collaborative learning with different roles. Virtual laboratory allows students to explore and establish students' science process skills and attitude. This study used a quasi experiment with nonequivalent control group design. Therefore, this study has add to the practical knowledge to develop science process skills and establish a positive attitudes of students toward science.
\end{abstract}

Keywords: POGIL; Virtual Laboratory; Science Process Skills; Scientific Attitude; Simple Harmonic Motion

\begin{abstract}
Abstrak
Gerak harmonik sederhana merupakan konsep yang sering melibatkan persamaan yang rumit dan dianggap sulit, sehingga siswa tidak dapat membangun pengetahuan terhadap konsep. Penelitian ini menerapkan model POGIL dengan virtual laboratorium, dimana siswa didorong untuk mengkontruksi konsep dan menekankan belajar kolaboratif dengan peran berbeda. Virtual laboratorium memudahkan siswa untuk bereksplorasi. Ini menumbuhkan keterampilan proses sains serta sikap ilmiah siswa. Metode penelitian yang digunakan adalah quasi eksperiment dengan desain nonequivalent control group. Oleh karena itu, penelitian ini menambah pengetahuan praktis untuk mengembangkan keterampilan proses sains dan menumbuhkan sikap positif siswa terhadap sains.
\end{abstract}

Keywords: Model POGIL; Virtual Laboratorium; Keterampilan Proses Sains; Sikap Ilmiah; Gerak Harmonik Sederhana

Permalink/DOI: http://dx.doi.org/10.15408/es.v10i2.10239

\section{INTRODUCTION}

Simple harmonic motion is a difficult concept for students to understand because it often involves a complex equation (Kareth, Dahlan, and Akbar 2018)(Obafemi and Onwioduokit 2013)(Iradat and Alatas 2017). Students are shy away from mathematical analysis of the concept, includes period, frequency, amplitude, velocity and acceleration of simple harmonic motion (Adolphus, Alamina, and Aderonmu 2013).

Simple harmonic motion can be observed using a spring and simple pendulum. This motion is a type of periodic motion or oscillation motion where the restoring force is directly proportional to the displacement and acts in the direction opposite to the displacement (Gowri, Deepika, and Krithika 2017). The spring that is stretched or compress around the equilibrium position is proportional to the force applied by force following Hooke's law, is given by (1):

$\mathrm{F}=-\mathrm{kx}$

Where $\mathrm{k}$ is a spring elastic constant and the measure $\mathrm{x}$ displacement of the equilibrium position (Gowri, Deepika, and Krithika 2017). 
Spring period is affected by the spring constant (k) and mass (m), The pendulum's period is given by (2): (Musik 2017)

$\mathrm{T}=2 \pi \sqrt{\frac{\mathrm{m}}{\mathrm{k}}}$

A pendulum with a length of rope and the mass $\mathrm{m}$ that is fixed rotating at the pivot point (Torzo and Peranzoni 2015). The period of motion is given by: (Neto 2017).

$\mathrm{T}=2 \pi \sqrt{\frac{1}{\mathrm{~g}}}$

Where $\mathrm{g}$ is the acceleration of gravity (Neto 2017).

A system which exhibits simple harmonic motion of amplitude (A), the position is given by the following equation: (Khotimah, Haris, and Viridi 2015)

$$
v x(t)=A \omega \cos \omega t
$$

Velocity equation in simple harmonic motion is given as follows: ( Gowri, Deepika, and Krithika 2017)

$$
v x(t)=A \omega \cos \omega t
$$

Acceleration quation in simple harmonic motion is given by the following: (Khotimah, Haris, and Viridi 2015)

$$
\alpha x(t)=-A \omega 2 \sin \omega t
$$

Simple harmonic motion does not require to decline that complicated equation as on kinematics motion. So that the delivery of the chapter can be implemented in a balanced between physical and mathematical analysis (Khowatim, Mahardika, and Harijanto 2017). Students having difficulty to understand the concept (Kareth, Dahlan, and Akbar 2018)(Obafemi and Onwioduokit 2013)(Iradat and Alatas 2017), due to students not actively construct knowledge in their own mind (Obafemi and Onwioduokit 2013) to build his own knowledge required skills, include science process skills (Ilmi, Desnita, Handoko, and Zelda 2016).. While the facts of physics learning activities has not been optimally trained the students' process skills (Ramayanti, Utari, and Puzaman 2017), as evidenced by the students' science process skills is low (Irwanto, Rohaeti,
Widjajanti, and Suyanta 2017)(Rahayu, Pratiwi, and Indana 2018)(Sukarno, Permanasari, and Hamidah 2013). Lack of discovery learning makes students' science process skills is low (Lati, Supasorn, and Promarak 2012). Teachers focus on the cognitive learning and rarely guide students by acquiring their skills (Rauf, Rasul, Mansor, Othman, and Lyndon 2013). It's important to develop science process skills to ensure that students master the concepts taught well (Sukarno, Permanasari, and Hamidah 2013). The skills needed for students to solve problems in the real life situation (Siahaan, Suryani, Kaniawati, Suhendi, and Samsudin 2017). Science process skills include measuring, classifying, interpreting, predicting, hypothesizing, communicating, applying concept, planning experiments, and inferring (Irwanto, Rohaeti, Widjajanti, and Suyanta 2017)(Zeidan and Jayosi 2014)(Suartini, Alatas, and Sukmawati 2014). Students build concept through scientific processes, then formed students' scientific attitudes (Putra, Abdurrahman, and Suana 2015).

Based on the problems mentioned above, it takes a didactic design involves students' opportunity to build knowledge, develop concepts and process skills that Process-Oriented, GuidedInquiry Learning (POGIL) model is designed (Chase, Pakhira, and Stains 2013). POGIL is a student-centered constructivist approach (Stanford, Moon, Towns, and Cole 2016),, involves students' developing their conceptual understanding collaboratively (Chase, Pakhira, and Stains 2013). Characteristics of POGIL use of the learning cycle (exploration, concept invention, and application) (Hanson 2006)(Rege, Havaldar, and Shaikh 2016), another possibility for the development of students' process skill (Sen, Yilmaz, and Geban 2016). Developing skills and process skills influencing the process of learning are very important in POGIL (Sen and Yilmaz 2015). Specific roles are also assigned to the members of a group as follows the manager, recorder, spokesperson, and strategy analyst (De Gale and Boisselle 2015) to support the team building process and to encourage the students participation and responsibility (Rege, Havaldar, and Syaikh 2016). The teacher teaches the content and process skills simultaneously (Sen and Yilmaz 2015). Learning process provides students 
opportunities to develop (Walker and Warfa 2017), and improve a scientific attitude during science content learning (Aktamis and Ergin 2008).

Most POGIL studies were carried out either over a long period of time (De Gale and Boisselle 2015)(Chase, Pakhira, and Stain 2013). That's good by using software simulation to better exploring the concept (Kahar, Esa, Tay, Hashim, Laham, and Wong 2016). One of them, that virtual laboratory enhance students' inquirys skills (Ranjan 2015), implementing time-consuming experiments and feedback in a shorter period of time (Gulsum and Didem 2017), in order to increase the effectiveness of learning (Sarı, Hassan, Guven, and Sen 2017). Virtual laboratory used were Phet simulation Colorado. Based on the explanation above, this study aims to apply the POGIL with Phet simulation Colorado in simple harmonic motion learning, and determine its effect on students' science process skills and attitude. The attitude of studied was attitude after learning, attention in students' academic ability.

\section{METHOD}

This study was conducted in MAN 3 Jakarta, with a total of 29 students, consisting of 8 male students and 21 female students. Characteristics of students were stratified into three academic ability goups, 7 of the students taught in highest academic ability, 13 in middle academic ability and 9 in low academic ability either the control or experimental group. Samples are students of class X IPA 1 as the control group and X IPA 2 as the experimental group.

This study used a quasi experiment (Pardimin and Arcana 2018), with nonquivalent control group design (Sugiyono 2015). Sampling technique is purposive sampling (Sarstedt, Bengart, Shaltoni, and Lehmann 2018). Instruments used to obtain data are science process skills tests, science process skills observation sheets and scientific attitude questionnaires. Science process skills tests include observing, classifying, interpreting, predicting, communicating, applying concept, planning experiments. Data were analyzed by using the N-Gain test on equation 1 (Coletta and Phillips 2005).

$$
\mathrm{N}-\text { Gain }=\frac{\text { posttest }- \text { pretest }}{100-\text { pretest }}
$$

Interpretation of N-Gain was $0<\mathrm{G}<0.3$ low category, $0.3 \leq \mathrm{G}<0.7$ middle category, and $0.7<\mathrm{G}$ high category (Hake 1998). Prerequisites test using normality (Kolmogorov-Smornov) and homogeneity test (Levene test). Hypothesis test using $\mathrm{T}$ test with $5 \%$ level of significance ( $\alpha=$ 0.05).

Attributes of scientific attitudes are curiosity, discovery and creativity, open-mindedness and cooperation, respect the data, critical thinking, perseverance, and respect for another's point of view. Data percentage is calculated using the following formula:

$$
\text { Percentage }=\frac{\text { score }}{\text { maximum score }} \times 100 \%
$$

Determinats of scientific attitude criteria is very good $(86-100 \%)$, good $(76 \%-85 \%)$, fair $(60 \%$ - 75\%), less $(55 \%$ - 59\%) and poor $(\leq 54 \%)$. (Purwanto 2006).

\section{RESULT AND DISCUSSION}

\section{Science Process Skills}

Science process skills include observing (C1), classifying (C2), interpreting (C3), predicting (C4), communicating (C5), applying concepts (C6), planning experiments (C7). Instruments test using multiple-choice test. Improved science process skills were tested using N-Gain based on a student's academic ability groups. The calculation results are presented in Table 1.

Table 1 shows the N-Gain results of science process skills based on students' academic ability. Students' high academic ability in control and experiment group had middle category. Students' middle and low academic ability in control group had low category, while the experimental group had a middle category. In POGIL, students are engaged in learning. Students understand to the phenomena observed, then collect the facts in the observation, summarize the results of the experiment, explained the results of the experiment, and connect these observations with the existing theory (Zamista and Kaniawati 2015). POGIL makes students trained to conclude data analysis (Umam and Subiki 2013). 
Before hypothesis testing, first is prerequisite test used normality and homogeneity test. Prerequisite test with $(\alpha)=0.05$ level of significance. Here is a prerequisite results in the study. Normality test used Kolmogorov-Smornov. The result of pretest and posttest normality on students' academic ability group as can be seen in Table 2.

Based on table 2, the significant result of pretest and posttest experiment and control group, for the low, middle, and high academic ability group is greater than the level of significance $(\alpha)$ or 0.05 , it can be concluded that pretest and posttest results of experiment and control group on each student's academic ability groups entirely normal distribution.

Homogeneity results of pretest and posttest based on students' academic ability group as can be seen in Table 3.

Based on table 3, the significant result of pretest and posttest experiment and control group, for the low, middle, or high academic ability is greater than the level of significance $(\alpha)$ or 0.05 , it can be concluded that the pretest and posttest results of experiment and control group on each academic ability were homogeneous.

Table 1. N-Gain Student Science Process Skills

\begin{tabular}{ccccccc}
\hline Aspects of & \multicolumn{2}{c}{ Low Academic Ability } & \multicolumn{2}{c}{ Middle Academic Ability } & \multicolumn{2}{c}{ High Academic Ability } \\
\cline { 2 - 7 } SPS & Control & Experiment & Control & Experiment & Control & Experiment \\
C1 & 0.16 & 0.44 & 0.15 & 0.61 & 0.43 & 0.77 \\
C2 & 0.07 & 0.33 & 0.05 & 0.33 & 0.11 & 0.40 \\
C3 & 0.12 & 0.46 & 0.11 & 0.62 & 0.40 & 0.78 \\
C4 & 0.06 & 0.31 & 0.04 & 0.25 & 0.10 & 0.30 \\
C5 & 0.14 & 0.43 & 0.12 & 0.60 & 0.38 & 0.64 \\
C6 & 0.13 & 0.36 & 0.13 & 0.48 & 0.41 & 0.56 \\
C7 & 0.05 & 0.37 & 0.03 & 0.48 & 0.38 & 0.55 \\
Average & 0.09 & 0.38 & 0.10 & 0.48 & 0.31 & 0.57 \\
Category & Low & Middle & Low & Middle & Middle & Middle \\
\hline
\end{tabular}

Table 2. Pretest and Posttest Normality Test

\begin{tabular}{|c|c|c|c|c|c|}
\hline Group & Academic ability & Test & Statistical & Signification & Description \\
\hline \multirow{6}{*}{ Experiment } & Low & Pretest & 0.255 & 0.187 & Normal \\
\hline & & Posttest & 0.255 & 0.187 & Normal \\
\hline & Middle & Pretest & 0.267 & 0.140 & Normal \\
\hline & & Posttest & 0,270 & 0.133 & Normal \\
\hline & High & Pretest & 0.255 & 0.187 & Normal \\
\hline & & Posttest & 0.256 & 0.182 & Normal \\
\hline \multirow[t]{6}{*}{ Control } & Low & Pretest & 0.205 & 0.200 & Normal \\
\hline & & Posttest & 0.152 & 0.200 & Normal \\
\hline & Middle & Pretest & 0.222 & 0.200 & Normal \\
\hline & & Posttest & 0.263 & 0.109 & Normal \\
\hline & High & Pretest & 0.222 & 0.200 & Normal \\
\hline & & Posttest & 0.196 & 0.200 & Normal \\
\hline \multicolumn{6}{|c|}{ Table 3. Pretest and Posttest Homogenity Test } \\
\hline \multicolumn{2}{|c|}{ Academic Ability Group } & Test & Statistical & Signification & Description \\
\hline \multirow{2}{*}{\multicolumn{2}{|c|}{ Low }} & Pretest & 0.078 & 0.926 & Homogen \\
\hline & & Posttest & 4.667 & 0.052 & Homogen \\
\hline \multirow{2}{*}{\multicolumn{2}{|c|}{ Middle }} & Pretest & 9,600 & 0,053 & Homogen \\
\hline & & Posttest & 5,000 & 0,053 & Homogen \\
\hline & & Pretest & 0,000 & 1,000 & Homogen \\
\hline & & Posttest & 0,400 & 0.561 & Homogen \\
\hline \multicolumn{6}{|c|}{ Table 4. Pretest and Posttest Hypothesis Test } \\
\hline \multirow{2}{*}{\multicolumn{2}{|c|}{ Academic Ability Group }} & \multicolumn{2}{|c|}{$\begin{array}{c}\text { Pretest } \\
\end{array}$} & \multicolumn{2}{|c|}{ Posttest } \\
\hline & & Signification & Description & Signification & Description \\
\hline \multicolumn{2}{|c|}{ Low } & 0.88 & Ha rejected & 0.00 & Ha accepted \\
\hline \multicolumn{2}{|c|}{ Middle } & 0.50 & Ha rejected & 0.00 & Ha accepted \\
\hline \multicolumn{2}{|c|}{ High } & 0.57 & Ha rejected & 0.00 & Ha accepted \\
\hline
\end{tabular}


Table 5. Relationship POGIL, Science Process Skills, Scientific Attitude, Cognitive Ability, and Simple Harmonic Motion Concept

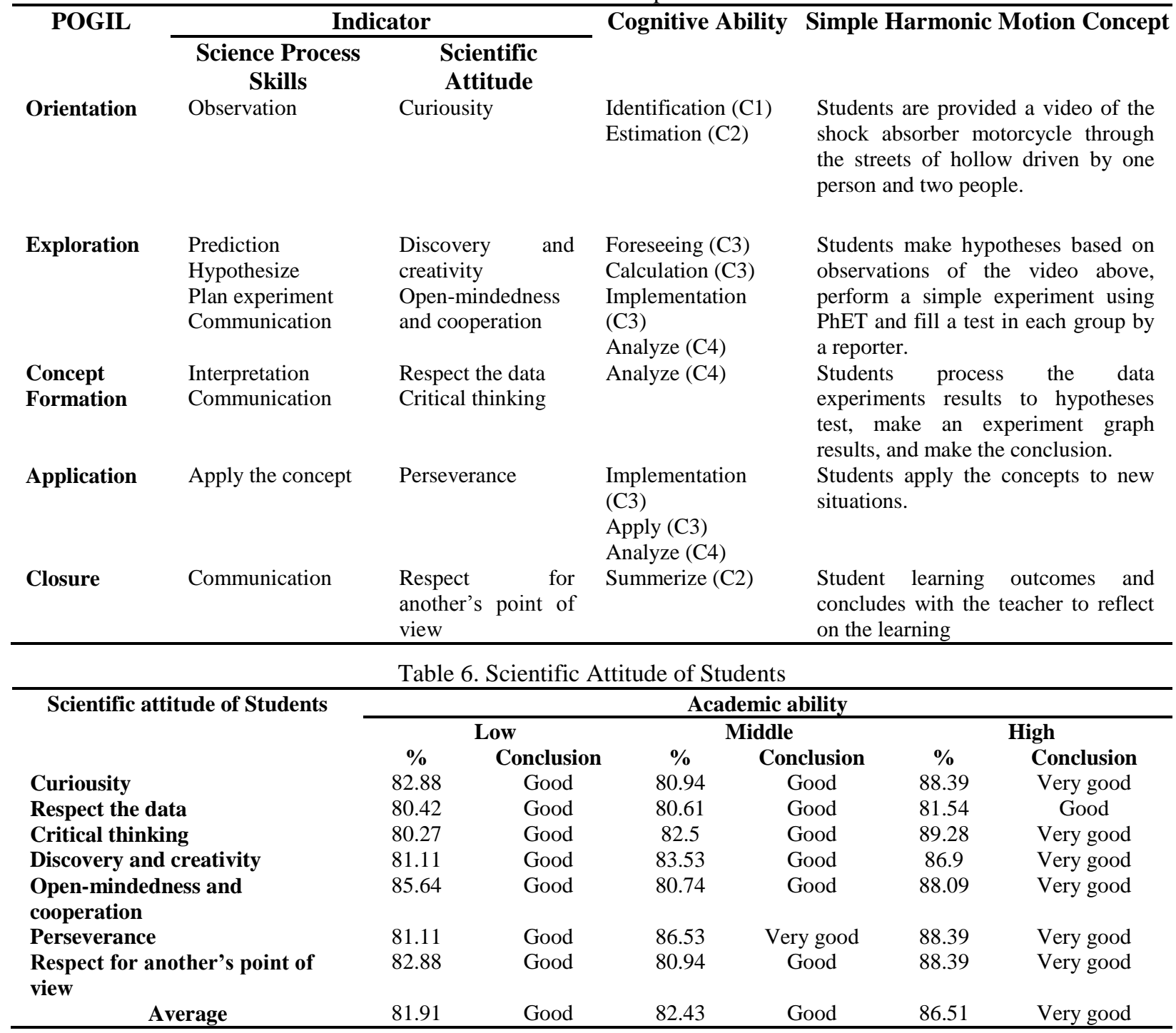

The results in this study were normal and homogeneous distribution for all academic ability groups. Therefore, hypothesis testing using parametric $\mathrm{T}$ test the hypothesis test calculation results are shown in Table 4.

Table 4 shows that the use of POGIL with virtual laboratory enhance students' science process skills of low, middle, and high academic ability group. Learning motivates students and they learn to interpret the concept well (Murray 2014). POGIL helps students to improve their skills in investigation (Barthlow and Watson 2014). Implementation of POGIL is recommended because it can develop students' skills and competences (Kahar, Esa, Tay, Hashim, Laham, and Wong 2016). POGIL is good to obtain scientific concepts and positive effect on students' understanding (Purnomo and Abadi 2015).
An explanation of the relationship between POGIL, science process skills, scientific aspects, cognitive ability, and simple harmonic motion concept presented in Table 5.

Table 5 illustrates the relationship between POGIL, science process skills, cognitive ability, and simple harmonic motion concept. Cognitive abilities in $\mathrm{C} 1$ (remembering), $\mathrm{C} 2$ (understanding), C3 (applying), and C4 (analyzing) associated with science process skills, POGIL, and simple harmonic motion concept. Study suggested that the use of POGIL impact on students to a better understanding and contribute to enhace grades and retention (Chase, Pakhira, and Stains 2013).

\section{Scientific Attitude}

The results of data analysis questionnaire students' scientific attitude are shown in Table 6. 
Table 6 shows that the students' scientific attitude of the high academic ability group $(86.51 \%)$ categorized very well. Scientific attitude related to the students' science process skills.

Students' science process skills who have a scientific attitude above the average is better than students' science process skills who have a scientific attitude below average (Hannasari, Harahap, and Sinulingga 2017). The majority of students have a positive impression on POGIL, students would prefer a POGIL learning, that help students cultivate a positive attitude toward learning, and change the perception of students towards subjects that are considered difficult. Student give a positive response to learning POGIL because it can improve students' performance (Sen, Yilmaz, and Geban 2016).

\section{CONCLUSION}

The use of POGIL with virtual laboratory had an advantage for students' science process skills in low, middle and high academic ability. POGIL help to increase students' science process skills, evidenced by increasing ability the process of science in middle category. Aspects of performance skills are developed: to observe, classify, interpret, predict, communicate, implement the concept, plan the experiments. Both model, POGIL with virtual lab help students to float the students' scientific attitude. Based on this, POGIL with virtual laboratory has a positive impact on science process skills and students' scientific attitude.

\section{ACKNOWLEDMENT}

Acknowledgments to the Faculty of Tarbiyah and Teachers Trainig (FITK) which has helped to provide research funding. Principal and the entire board of teachers Madrasah Aliyah (MAN) 3 Jakarta which have assisted research permition and help during research process.

\section{REFERENCES}

Adelia, A. Z. \& Ida K. (2015). Pengaruh Model Pembalajaran Process Oriented Guided Inquiry Learning (POGIL) Terhadap Keterampilan Proses Sains Dan Kemampuan Kognitif Siswa
Pada Mata Pelajaran Fisika. Edusains 7(2):191-201.

Afif, H. Z. \& Majdi, R. J. (2014). Science Process Skills and Attitudes toward Science among Palestinian Secondary School Students. World Journal of Education 5(1):13-24.

Akash, R. (2015). Effect of Virtual Laboratory on Students' Conceptual Achievement in Physics. International Journal of Technical Research \& Science 2(1):15-21.

Courtney, S., Alena, M., Marcy, T., \& Renee, C. (2016). Analysis of Instructor Facilitation Strategies and Their Influences on Student Argumentation: A Case Study of a Process Oriented Guided Inquiry Learning Physical Chemistry Classroom. Journal of Chemical Education 93(9):1-13.

David, M. H. (2006). Instructor's Guide to Process-Oriented Guided-Inquiry Learning. New York: Pacific Crest.

Deborah, T. A. O., \& Fidelis, A. O. (2013). Identification of Difficult Concepts in Senior Secondary School Two ( SS2 ) Physics Curriculum in Rivers State, Nigeria. Asian Journal of Education and E-Learning 01(05):317-22.

E. Wiwin \& R. Kustijono. (2018). The Use of Physics Practicum to Train Science Process Skills and Its Effect on Scientific Attitude of Vocational High School Students. Journal of Physics: Conference Series 1-8.

Giacomo, T., and Paolo, P. (2015). The Real Pendulum: Theory, Simulation, Experiment. Journal Physics Education 3(2):221-28.

Gulsum, A. \& Islek, D. (2017). The Impact of the Virtual Laboratory on Students' Attitudes in a General Physics Laboratory. International Journal of Online Engineering (i-Joe) 13:2028.

H. Pardimin \& N. Arcana. (2018). Fulfilling the Law of A Single Independent Variable and Improving The Result of Mathematical Educational Research. Journal of Physics: Conference Series 1-6.

Hilal, A. \& Omer, E. (2008). The Effect of 
Scientific Process Skills Education on Students' Scientific Creativity, Science Attitudes and Academic Achievements. AsiaPacific Forum on Science Learning and Teaching 9(1):1-21.

Irwanto, Eli, R., Endang, W., \& Suyanta. (2017). Students' Science Process Skill and Analytical Thinking Ability in Chemistry Learning. AIP Conference Proceedings 1-4.

Joao, P. J .N. (2017). Solving The Nonlinear Pendulum Equation With Nonhomogeneous Initial Conditions. International Journal of Applied Mathematics 30(3):259-66.

Kinkin, S., Fathiah, A., \& Gema, S. (2014). Effects of Virtual Experiment Media on Students' Scientific Process Skills in Understanding Thermodynamics Concepts. International Conference on Education in Muslim Society (ICEMS) 283-301.

Lindsey, W. \& Abdi, R. M. W. (2017). Process Oriented Guided Inquiry Learning (POGIL) Marginally Effects Student Achievement Measures but Substantially Increases The Odds of Passing A Course. PLOS ONE 12(10):1-17.

M. Syaikhul, U., Indrawati, \& Subiki. (2013). Pengaruh Model Process Oriented Guided Inquiry Learning (POGIL) Terhadap Hasil Belajar Dan Retensi Hasil Belajar Siswa Pada Pembelajaran Fisika SMA/MA Di Kabupaten Jember. Jurnal Pembelajaran Fisika 5(3):205-10.

Marko, S., Paul, P., Abdel, M. S., \& Sebastian, L. (2018). The Use of Sampling Methods in Advertising Research: A Gap Between Theory and Practice. International Journal of Advertising 37(4):650-63.

Mega, E. R. P. \& Agus, M. A. (2015). The Implementation of Pogil in Mathematics Learning Process to Develop Students' Competences Within Curriculum 2013. Proceeding of International Conference On Research, Implementation And Education Of Mathematics And Sciences 3(7):265-72.

Michelle, J. B. \& Scott, B. W.. (2014). The Effectiveness of Process-Oriented Guided
Inquiry Learning to Reduce Alternative Conceptions in Secondary Chemistry. School Science and Mathematics 114(5):246-55.

Nazwatul, I., Desnita, D., Erfan, H., \& Betty, Z. (2016). Pengembangan Instrumen Penilaian Keterampilan Proses Sains Pada Pembelajaran Fisika SMA. Prosiding Seminar Nasional Fisika (E-Journal) SNF2016 5:57-62.

Ngalim, P. (2006). Prinsip-Prinsip Dan Teknik Evaluasi Pengajaran. Bandung: PT Remaja Rosdakarya.

Nur, A. R. P, Abdurrahman, \& Wayan, S. (2015). Pengaruh Ketreampilan Proses Sains Dan Sikap Ilmiah Terhadap Pemahaman Konsep IPA. Jurnal Pembelajaran Fisika 3(2):33-42.

P. Gowri, D., Deepika, \& S. Krithika. (2017). “A Case Study on Simple Harmonic Motion and Its Application." International Journal of Latest Engineering and Management Research (IJLEMR) 02(08):51-60.

P. Siahaan, A. Suryani, E. Suhendi, \& A. Samsudin. (2017). Improving Students' Science Process Skills through Simple Computer Simulations on Linear Motion Conceptions. Journal of Physics: Conference Series 1-5.

Panjit, M. (2017). Development of ComputerBased Experiment Set on Simple Harmonic Motion of Mass on Springs. Turkish Online Journal of Educational Technology 16(4):111.

Pralhad, R., Freddy, H., \& Gulshan, S. (2016). An Effective Use of POGIL in Improving Academic Performance of Students and Their Approach in Organic Chemistry. International Journal of Science and Research Methodology (IJSRM) 4(1):45-61.

R. D. Iradat \& F. Alatas. (2017). The Implementation of Problem-Solving Based Laboratory Activities to Teach the Concept of Simple Harmonic Motion in Senior High School. Journal of Physics: Conference Series $1-7$.

Richard, R. H. (1998). Interactive-Engagement versus Traditional Methods: A Six-ThousandStudent Survey of Mechanics Test Data for 
Introductory Physics Courses. American Journal of Physics 66(1):64-74.

Rinapril, H., Mara, B. H., \& Karya, S. (2017). Effect of Scientific Inquiry Learning Model on the Student' $\mathrm{s}$ Generic Science Skill Process Science Students. Journal of Education and Practice 8(21):48-52.

Rose, A. A. R., Mohamad, S. R., Azlin, N. M., Zarina O., \& N. Lyndon. (2013). Inculcation of Science Process Skills in A Science Classroom. Asian Social Science 9(8):47-57.

Rosmila, A. K., Fahmiruddin, E., Kim, G. T., Rathiah, H., Mohamad, N. L., \& Brian, Y. L. W. (2016). Finite Element Analysis (FEA) in Electronics Devices and Photonics through Process Oriented Guided Inquiry Learning (POGIL). Journal of Telecommunication, Electronic and Computer Engineering 8(6):93-97.

S. De Gale \& L. N. Boisselle. (2015). The Effect of POGIL on Academic Performance and Academic Confidence. Science Education International 26(1):56-79.

S. Ramayanti, S. Utari, \& D. Sae Puzaman. (2017). Training Students' Science Process Skills through Didactic Design on Work and Energy. Journal of Physics: Conference Series 1-7.

Senol, S., Ayhan, Y., \& Omer, G. (2016). High School Students' Views about Process Oriented Guided Inquiry Learning (POGIL). The Turkish Online Journal of Educational Technology - TOJET 1114-19.

Senol. S \& Ayhan, Y. (2015). The Effects of Process Oriented Guided Inquiry Learning Environment on Students' Self-Regulated Learning Skills. Problems of Education in the 21st Century 66:54-66.

Siti, N. K., Luman H., \& Sparisoma Viridi. Natural Sciences. (2015). Simple Harmonic Motion Experiment Using Force Sensor: Low Cost and Single Setup. The Online Journal of Science and Technology - TOJSAT 5(1):5562.

Siti, P. K. K., I. Ketut, M., \& Alex, H. (2017). Study of Simple Harmonic Motion's Subject Assisted Worksheet Based on MGR with
Learning Setting of Poe. Pancaran Pendidikan 6(3):110-19.

Sugiyono. (2015). Metode Penelitian Pendidikan (Pendekatan Kuantitatif, Kualitatif, Dan $R$ \& $D)$. Bandung: Alfabeta.

Sukarno, Anna, P., \& Ida, H. (2013). The Profile of Science Process Skill (SPS) Student at Secondary High School (Case Study in Jambi). International Journal of Scientific Engineering and Research (IJSER) 1(1):7983.

Telima, A. S, Jane A., \& Temitope A. (2013). The Effects of Collaborative Learning on Problem Solving Abilities among Senior Secondary School Physics Students in Simple Harmonic Motion. Journal of Education and Practice 4(25):95-101.

Tracey, A. M. (2014). Teaching Students to Read The Primary Literature Using Pogil Activities. Biochemistry and Molecular Biology Education 42(2):165-73.

Ugur, S., Abdillahi, H., Kutalmıs, G., \& Omer, F. (2017). Effects of the 5E Teaching Model Using Interactive Simulation on Achievement and Attitude in Physics Education 25(3):2035.

Vincent, P. C. \& Jeffrey, A. P. (2005). Interpreting FCI Scores: Normalized Gain, Preinstruction Scores, and Scientific Reasoning Ability. American Journal of Physics 73(12):1172-82.

Wichai, L., Saksri, S., \& Vinich, P. (2012). Enhancement of Learning Achievement and Integrated Science Process Skills Using Science Inquiry Learning Activities of Chemical Reaction Rates. Procedia - Social and Behavioral Sciences 46:4471-75.

Y. S. Rahayu, R. Pratiwi, \& S. Indana. (2018). Development of Biology Student Worksheets to Facilitate Science Process Skills of Student. IOP Conference Series: Materials Science and Engineering 1-11.

Zakaria, V. K., Khaeriah, D., \& Muhammad, A. (2018). Harmonic Oscillation Characteristic Using Visual Basic Application. Journal of Physics: Conference Series 1-5. 